\section{Case Reports in Dermatology}

Case Rep Dermatol 2017;9:206-210

DOI: $10.1159 / 000481771$

Published onlıne: Uctober 20, 2017

(C) 2017 The Author(s)

Published by S. Karger AG, Basel

www.karger.com/cde

This article is licensed under the Creative Commons Attribution-NonCommercial 4.0 International License (CC BY-NC) (http://www.karger.com/Services/OpenAccessLicense).

Usage and distribution for commercial purposes requires written permission.

\title{
CD30+ Cutaneous Anaplastic Large-Cell Lymphoma of the Upper Eyelid: A Case Report
}

\author{
Stéphanie Olivier ${ }^{a} \quad$ Claire Dachelet $^{b} \quad$ Ivan Theate $^{c} \quad$ Isabelle Tromme ${ }^{a}$ \\ Marie Baeck ${ }^{\mathrm{a}}$ \\ a Department of Dermatology, Cliniques Universitaires Saint-Luc, Université Catholique de \\ Louvain, Brussels, Belgium; ${ }^{b}$ Department of Dermatology, CHU UCL Namur, Yvoir, Belgium; \\ 'Department of Pathology, Institut de Pathologie et de Génétique (IPG), Gosselies, Belgium
}

\section{Keywords}

CD30+ cutaneous anaplastic large-cell lymphoma $\cdot$ Eyelid $\cdot$ Lymphoma $\cdot$ T-cell lymphoma

\begin{abstract}
CD30 + cutaneous anaplastic large-cell lymphoma is part of the CD30+ T-cell lymphoproliferative disorders. This type of lymphoma is in most cases indolent, with a high survival rate. We report the case of a 59-year-old patient with a 1-month lasting crusty lesion of the upper eyelid. Eyelid involvement is very uncommon, as the most frequent locations are the trunk and the limbs.

(C) 2017 The Author(s)

Published by S. Karger AG, Basel
\end{abstract}

\section{Introduction}

It can be difficult to diagnose a CD30+ cutaneous anaplastic large-cell lymphoma (ALCL), especially when the clinical presentation is uncommon. The final diagnosis is generally made by taking the clinical aspect into account, the evolution, and the pathology of the lesion. 


\section{Case Report}

We report the case of a 59-year-old female patient who presented with a painless lesion of the left upper eyelid (Fig. 1) for 1 month. The lesion was roundish and crusted and had an infiltrated appearance. No peripheral lymph nodes were found. The bacteriological culture from the swab was negative and the skin biopsy was not relevant, probably due to insufficient skin material obtained. The lesion was thus completely excised by means of a bilateral blepharoplasty (Fig. 2).

The pathological analysis (Fig. 3) showing a dense lymphocytic infiltration, with a coexpression of CD8 and CD30 antigen (Fig. 4), could have been either in favor of a CD30+ lymphoproliferation or a primary cutaneous CD8+ aggressive epidermotropic cytotoxic T-cell lymphoma.

Regarding the good general health of the patient, the clinical examination, the immunopathological analysis, and the PET scan (showing no particularity), the diagnosis of a primary cutaneous CD30+ ALCL was made. After 2 years, we did not notice any sign of relapse at clinical examination.

\section{Discussion}

Primary cutaneous CD30+ T-cell lymphoproliferations (that account for $20-30 \%$ of the cutaneous lymphomas) include CD30+ cutaneous ALCL, lymphomatoid papulosis, but also "atypical" (borderline) cases.

CD30+ cutaneous ALCL is an indolent lymphoma, with a survival rate of $96 \%$ at 5 years [1]. It is often an asymptomatic, unique, reddish-purple nodular lesion. The surface may often be ulcerated. The most frequent locations are the trunk and limbs. In this case, the lesion was located on the upper eyelid, which is a very uncommon location. In the literature, we found only 12 cases of CD30+ cutaneous ALCL involving the eyelid [2-12]. Only 5\% of ocular adnexal lymphomas involve the eyelid, among which only $44 \%$ are of $\mathrm{T}$-cell origin, most frequently represented by mycosis fungoides $(13 \%)$, high-grade extranodal natural killer/Tcell lymphoma (6\%), and low-grade primary cutaneous ALCL (6\%) [13]. CD30+ cutaneous ALCL seems to affect more frequently the upper eyelid (83\%) compared to the lower eyelid [13], which was the case for our patient.

Pathological analysis usually shows atypical cells with a variable morphology (anaplastic, pleomorphic, or immunoblastic). At least $75 \%$ of the tumoral cells strongly express the CD30 antigen [14].

The clinical examination, the evolution, and the pathological analysis should be considered all together before making this diagnosis, when the clinical presentation is atypical.

Spontaneous regression is observed in approximately $30 \%$ of the cases [15]. In other cases, the treatment of localized forms consists in surgery, with or without radiotherapy. Recurrences after local treatment are, however, frequent (about 50\%), but they do not alter the long-term prognosis. In disseminated form, polychemotherapy must be considered as there is a greater risk of extracutaneous extension.

In conclusion, CD30+ cutaneous ALCL is a relatively common type of cutaneous lymphoma. Palpebral involvement is very rare, but this diagnosis should nevertheless be evoked when a lesion of this type occurs. 


\section{Acknowledgements}

Acknowledgements to Prof. Liliane Marot, Dr. Alessandra Camboni, and Dr. Pascal Van Eeckhout for their contribution.

\section{Statement of Ethics}

The authors state that the subject has given her informed consent.

\section{Disclosure Statement}

The authors have no conflicts of interest to disclose.

\section{References}

1 Bekkenk M, Geelen F, van Voorst Vader P, Heule F, Geerts ML, van Vloten WA, Meijer CJ, Willemze R: Primary and secondary cutaneous CD30+ lymphoproliferative disorders: a report from the Dutch Cutaneous Lymphoma Groupe on the long-term follow-up data of 219 patients and guidelines for diagnosis and treatment. Blood 2000;95:3653-3661.

2 Koestinger A, McKelvie P, McNab A: Primary cutaneous anaplastic large-cell lymphoma of the eyelid. Ophtalmology 2010;117:343-351.

-3 Sanka RK, Eagle RC Jr, Wonjo TH, Neufeld K, Grossniklaus H: Spectrum of CD30+ lymphoid proliferations in the eyelid: lymphomatoid papulosis, cutaneous anaplastic large cell lymphoma and anaplastic large cell lymphoma. Ophtalmology 2010;117:343-351.

-4 Yamane N, Kato N, Nishimura M, Ito M, Yanagi T, Osawa R: Primary cutaneous CD30+ anaplastic largecell lymphoma with generalized skin involvement and involvement of one peripheral lymph node, successfully treated with low-dose oral etoposide. Clin Exp Dermatol 2009;34:56-59.

-5 Tanzi E, Edelmans M, Rosenbaum PS: Ki-1-positive anaplastic large-cell lymphoma of the eyelid. Arch Ophtalmol 1999;117:955-958.

-6 Segal Zi, Cohen I, Szvalb S, Weyl-Ben-Arush M, Rehany U: Solitary extranodal anaplastic large cell lymphoma, K-1+, of the eyelid. Am J Ophtalmol 1997;124:105-107.

-7 Fujita H, Nagatani T, Miyazawa M, Wada H, Koiwa K, Komatsu H, Ikezawa Z: Primary cutaneous anaplastic large cell lymphoma successfully treated with low-dose oral methotrexate. Eur J Dermatol 2008;18:360-361.

-8 Coupland SE, Foss HD, Assaf C, Auw-Haedrich C, Anastassiou G, Anagnostopoulos I, Hummel M, Karesh JW, Lee WR, Stein H: T-cell and T/natural killer-cell lymphomas involving ocular and ocular adnexal tissues: a clinicopathologic, immunohistochemical, and molecular study of seven cases. Ophtalmology 1999;106:2109-2120.

-9 Martin JM, Ricart JM, Monteagudo C, Alcácer J, Pinazo I, Tomás L, Rausell N, Jordá E: Primary cutaneous CD30+ anaplastic large-cell lymphomas mimicking keratoacanthomas. Clin Exp Dermatol 2007;32:668-671.

10 Turrión-Merino L, Perez-Gala S, Hermosa-Zarza E, Urech-García-de-la-Vega M, Carrillo-Guijón R, JaénOlasolo P: Primary cutaneous CD30+ anaplastic large cell lymphoma treated with radiotherapy and methotrexate with development of xanthomas at the sites of prior disease. J Cutan Pathol 2016;43:400405.

-11 Moon HR, Park GH, Jung JM, Won CH, Chang SE, Lee MW, Choi JH, Moon KC: A case of anaplastic largecell lymphoma mimicking preseptal cellulitis. Clin Exp Dermatol 2014;39:77-78.

12 Koreen IV, Cho RI, Frueh BR, Elner VM: Primary cutaneous anaplastic large cell lymphoma of the medial canthus and orbit. Ophthal Plast Reconstr Surg 2009;25:63-65.

$\checkmark 13$ Svendsen FH, Heegaard S: Lymphoma of the eyelid. Surv Ophthalmol 2017;62:312-331.

14 Tbatou F, Hassam B: Primary cutaneous anaplastic lymphoma with large cells presenting as a solitary nodule. Pan Afr Med J 2013;15:51.

15 Beylot-Barry M, Dereure O, Vergier B, Barete S, Laroche L, Machet L, Delfau-Larue MH, D'IncanM, Grange F, Ortonne N, Merlio JP, Bagot M: Prise en charge des lymphomes T cutanés: recommandations du Groupe français d'étude des lymphomes cutanés. Ann Dermatol Venereol 2010;137:611-621. 


\section{Case Reports in Dermatology}

\begin{tabular}{l|l}
\hline Case Rep Dermatol 2017;9:206-210 \\
\hline DOI: 10.1159/000481771 & $\begin{array}{l}\text { C } 2017 \text { The Author(s). Published by S. Karger AG, Basel } \\
\text { www.karger.com/cde }\end{array}$ \\
\hline
\end{tabular}

Olivier et al:: CD30+ Cutaneous Anaplastic Large-Cell Lymphoma of the Upper Eyelid: A Case Report

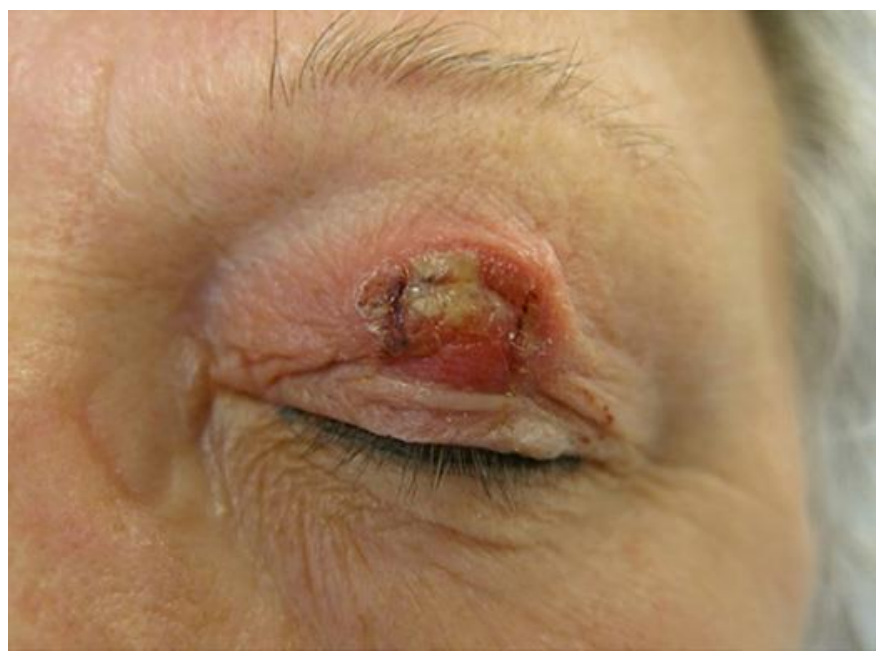

Fig. 1. Clinical aspect of a primary cutaneous CD30+ anaplastic large-cell lymphoma located on the left upper eyelid.

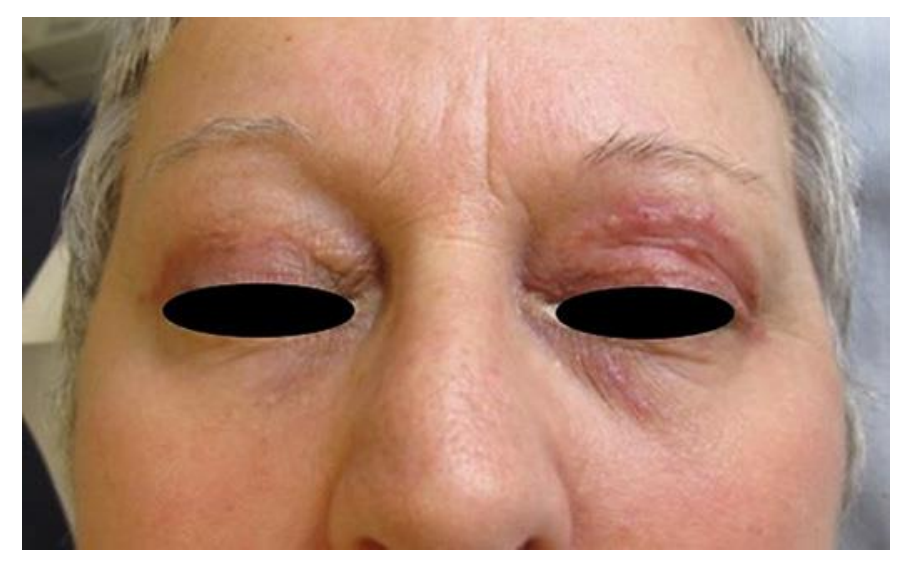

Fig. 2. Appearance of the eyelids after bilateral blepharoplasty. 


\section{Case Reports in Dermatology}

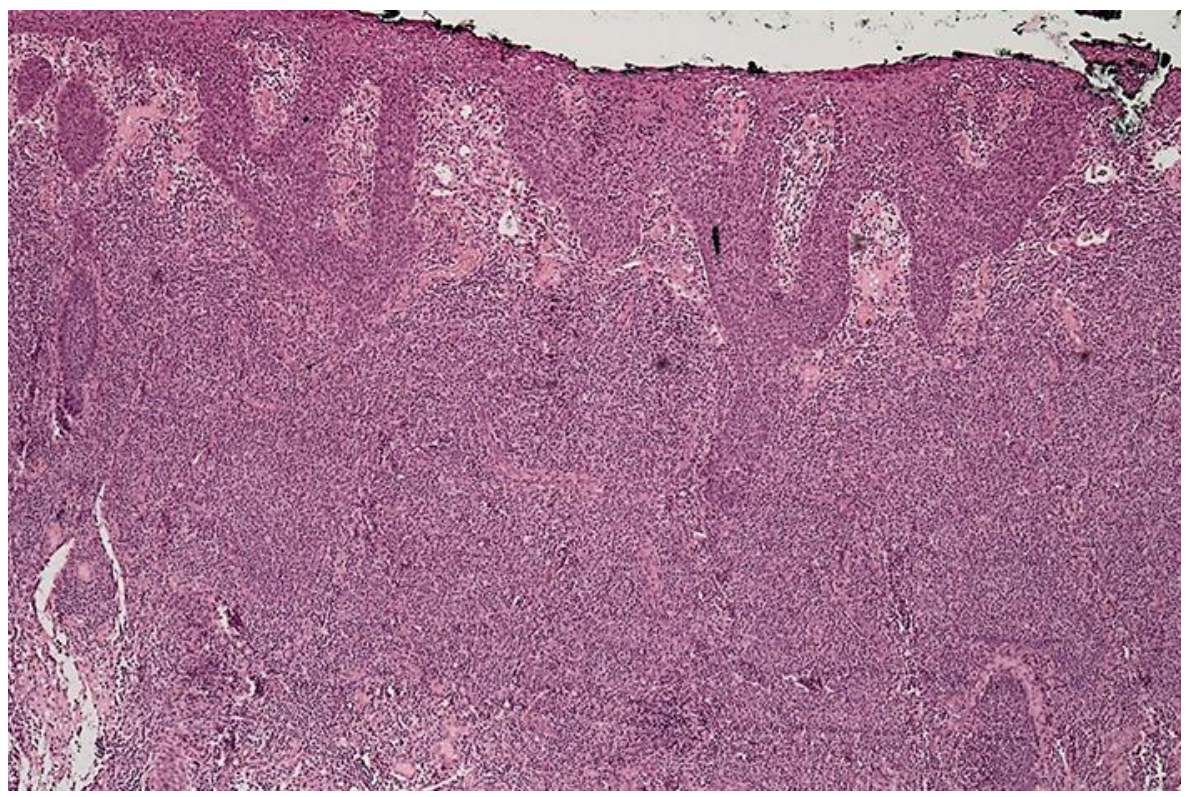

Fig. 3. Pathological analysis. Massive infiltration of the epidermis and the dermis by small atypical lymphocytes (hematoxylin-eosin, original magnification $\times 50$ ).

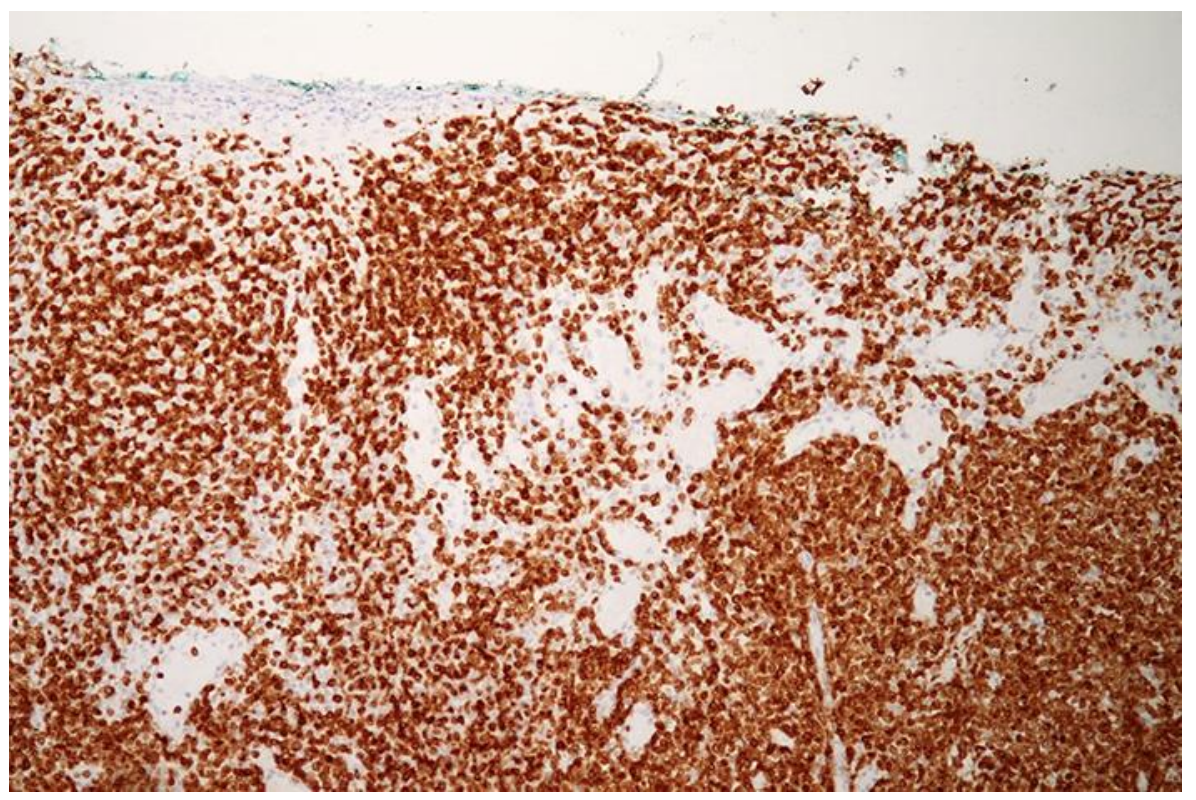

Fig. 4. Immunopathological analysis. Strong positivity for CD30 and CD8. Note the important lymphocytic epidermotropism (CD30 immunohistochemistry, original magnification $\times 100)$. 